\title{
Women and Gender in European Politics Courses: Exploring the Scandinavian Welfare States
}

\author{
Leslie C. Eliason, University of Washington
}

$\mathbf{R}$ esearch on women and gender issues in European societies has expanded dramatically over the past 25 years, responding to the explosion in women's participation in paid employment outside the home, their increasing participation in public life, and their presence in the academic research community. In northern Europe, their status has improved in certain areas so much that the Nordic countries are now commonly viewed as paradises for women. This perception is largely due to their widespread commitment to equality and a well-developed system of publicly-funded social services, income security, education, health care, and day care (Fougner and Larsen-Asp 1994).

Admittedly, few universities have the luxury of offering a course devoted to women in Scandinavian society and politics. But if we are serious about integrating feminist perspectives into the core curriculum, one way to start is by looking at the welfare state in northern Europe and focusing on the importance of sex and gender in the Scandinavian welfare state. Gendered analysis changes the way we think about the welfare state and how it has influenced and is influenced by social and economic relations. Thus Scandinavian material can become a starting point for the inclusion of women and gender issues in other parts of our courses and curricula.

It is important to note that most accessible texts dealing with Scandinavian politics and society do not adequately treat gender issues. For example, Esping-Andersen's Politics Against Markets (1985) makes almost no mention of the changing position of women. Einhorn and Logue's Modern Welfare States (1989) has some coverage, but is not sensitive enough to the important ways in which gendering changes our interpretations and evaluations (e.g., Sainsbury 1994; Hernes 1988; Sassoon 1987; Dahlerup 1986; Haavio-
Mannila, et al. 1985). On the other hand, feminist scholars have contributed critical perspectives and findings, but these will only have meaning for an undergraduate audience that already understands the mainstream literature on the social democratic welfare state. Thus, one has to alternate between main texts and auxiliary readings. Unfortunately, this tends to reinforce the inclusion of women only as an afterthought. We want to challenge this perpetuation of the status quo.

There are several basic insights that come from gendered analyses of the welfare state. First, the social democratic welfare states were first established before the inclusion of women in the democratic process. Exploring the roots of the welfare state, therefore, requires making visible women's invisibility in the politics of the era of early industrialization. The cornerstones of the social democratic welfare state were designed to provide income maintenance in cases of sickness, disability, or old age. These insurance programs, often first organized by labor unions, emerged when the male wage earner was head of the household and the wife cared for home and family unpaid. Thus the institutional basis of the welfare state emerged within the context of a male "breadwinner" model and the welfare state is marked by its preWorld War II emergence and development within a historical period characterized by this division of labor. Students should be encouraged to examine how the roots of the welfare state and its pre-war provisions emerged to support and perhaps reinforce the gendered division of labor.

Second, the dramatic post-industrial expansion of the welfare state took place at about the same time as the equally dramatic increase in women's participation in the paid labor market. The increased participation of women in the labor market has had push-pull effects on public policy, especially in areas involving child care, maternity benefits, parental leave, and equal opportunitiespolicies that support women in the work force (Haas 1992). The first two decades after World War II are often cited as the most important period of expansion of the welfare state in Europe. However, if we track the expansion of the public sector, the second half of the 1960 s and the 1970 s really constituted the most dramatic period of growth. Not coincidentally, this is also the period in which women's participation in the labor market grew most rapidly. As Jorgen Goul Andersen's (1992) work demonstrates, these are crucial factors in understanding the dynamics of class politics and social change in Scandinavia during the postwar era.

Third, scholars have also pointed to the feminization of the welfare state, referring to the fact that women now constitute a major segment of the population served by welfare state policies and programs and also constitute the majority of the public sector employees providing these services or working in the agencies administering these programs. By contrast, women do not constitute the majority of the decision-makers who formulate the rules governing the administration of these benefits.

Fourth, the increasing involvement of the state in these "caring functions," particularly for the young, the old, the infirm, and the physically or mentally impaired has spurred debate about the "politics of caring" (e.g., Waerness 1987; Waerness and Ringen 1987). What difference does it make that the caring functions traditionally performed by women within the family and the local community have been transferred to the public sector where they are provided within an institutional structure and where caregivers are financially remunerated for their services? 
Introducing the politics of caring debate opens the way for classroom discussion of the distinction between the public and private spheres and how the changing boundaries between our private lives (the home) and our public activities (work, politics, community action) are influenced by and, in turn, affect our expectations about the role of the state in providing well-being and prosperity. To start debate, you may ask students if women swapped dependency on men within the family structure for dependence on the state, and thus dependence on predominantly male decision-makers (Hernes 1987, 1988; Siim 1988; Dahlerup 1994)?

Fifth, quota systems within most Nordic political parties ensure at least $40 \%$ female representation on party lists and party leadership. Nordic countries currently boast of the highest proportion of women legislators in liberal democracies. Despite this fact, Scandinavian countries still display significant gaps between men and women. For example, even the utilization pattern of incomie maintenance programs bears out gender differences (Sainsbury 1983). Thus the Scandinavian cases provide us with a valuable launching point for a discussion about the limits of legal and institutional reform in bringing about fundamental changes in the gendered distribution of power, influence, property, and wealth (Hansen 1987; Ruggie 1984). One important aspect of this discussion is the question of corporatism's role in public policy-making and the degree to which organized labor helps or hinders the interests of women. Another way of thinking about change is whether numbers alone matter. Dahlerup (1988) encourages us to think in terms of critical acts rather than critical mass.

Exploring gender relations and the status of women is not something reserved exclusively for the study of European politics. Thinking about gender, sex, politics, and power in advanced welfare states around the world helps us link theory with empirical experience and gender studies with political science. Indeed, in the context of the debate about welfare reform in this country, teachers should look even more to comparing and contrasting the Scandinavian welfare state with that of the United State.

The teacher should be prepared for the possibility that many students have not encountered feminist analysis before. Colleagues in Women's Studies programs and departments can be valuable in assisting political scientist to cope with any unexpected reactions this material can provoke in the classroom. Learning about women and the welfare state can enrich our students' experiences and also our own professional development.

A course on European society and politics must address the impact of the welfare state. To appreciate the importance of the welfare state, we must understand "how the division of labour among the sexes and gender ideologies shape social provision and, in turn, how social policies affect the life situations of women and men across welfare states" (Sainsbury 1995,7$)$. In exploring the range of provision of welfare services and programs in Scandinavia, students can also critically examine the limits to which the liberal state can, through democratic means, alter fundamental social norms, mores, and values. The remarkable strength of gender roles and the ways in which institutions, public and private, reinforce inequities can be revealed while simultaneously appreciating the impressive achievements of the Scandinavian welfare states in furthering progress toward a more egalitarian society.

\section{References}

Andersen, Jorgen Goul. 1992. "The Decline of Class Voting Revisited." In From Voters To Participants: Essays In Honour of Ole Borre, eds. Peter Gundelach and Karen Siune, 91-107. Aarhus, Denmark: Politica.

Dahlerup, Drude. 1988. "From a Small to a Large Minority: Women in Scandinavian Politics." Scandinavian Political Studies 11(4):275-98.

Dahlerup, Drude. 1994. "Learning to Live with the State: State, Market, and Civil Society, Women's Need for State Intervention in East and West." Womens Studies International Forum 17(2-3):117-28.
Esping-Andersen, Gosta. 1985. Politics Against Marketing: The Social Democratic Road to Power. Princeton: Princeton: Princeton University Press.

Einhorn, Eric and John Logue. 1989. Modern Welfare States: Politics and Policies in Social Democratic Scandimaria. New York: Praeger.

Fougner, Brit and Mona Larsen-Asp, eds. 1994. The Nordic Countries-a Paradise for Women? Nord 1994:16. Copenhagen: Nordic Council of Ministers.

Haas, Linda. 1992. Equal Parenthood and Social Policy: A Study of Parental Leave in Sweden. Albany: State University of New York Press.

Haavio-Mannila, Elina, et al. 1985. Unfinished Democracy: Women in Nordic Politics. New York: Pergamon Press.

Hansen, Erik Jorgen. 1987. "Inequality in the Welfare State." In The Scandinavian Model, eds. Robert Erikson et al, 109-121. New York: M. E. Sharpe.

Hernes, Helge Maria. 1987 "Women and the Welfare State: The Transition From Private to Public Dependence." In Women and the State, ed. Anne Showstack Sassoon, 72-92. London: Hutchinson.

Hernes, Helge Maria. 1988. Welfare State and Women Power: Essays in State Feminism. Oslo: Norwegian University Press.

Ruggie, Mary. 1984. The State and Working Women: A Comparative Study of Britain and Sweden. Princeton: Princeton University Press.

Sainsbury, Diane. 1984. "Dual Welfare and Sex Segregation of Access to Social Benefits: Income Maintenance Policies in the UK, the US, the Netherlands and Sweden." Journal of Social Policy 22(1):66-99.

Sainsbury, Diane ed. 1995. Gendering Welfare States. Thousand Oaks, CA: Sage.

Sassoon, Anne Showstack, ed. 1987. Women and the State. London: Hutchinson.

Siim, Birte. 1988. "Towards a Feminist Rethinking of the Welfare State." In The Political Interests of Gender, eds. Kathleen B. Jones and Anna G. Jónasdóttir. London: Sage.

Waerness, Kari. 1987. "On the Rationality of Caring." In Women and the State, ed. Anne Showstack Sassoon, 207-34. London: Hutchingson.

Waerness, Kari and Stein Ringen. 1986. "Women in the Welfare State: The Case of Formal and Informal Old-Age Care." In The Scandinavian Model, eds. Robert Erikson et al, 161-73. New York: M. E. Sharpe.

\footnotetext{
About the Author

Leslie Eliason is assistant professor, University of Washington, where she heads the international and comparative specialization of the MPA program. Her research on comparative public policy focuses on the politics of reform in education and social policy in Western and Eastern Europe.
} 